\title{
Application of hormonal subdoses at the Bai Hui acupoint for estrus synchronization in sheep
}

\section{Aplicação de subdoses hormonais no ponto de acupuntura Bai Hui para sincronização de estro em ovelhas}

\author{
Diego Oliveira Souza ${ }^{1}$; Carmo Emanuel Almeida Biscarde ${ }^{2}$; William Morais \\ Machado3; Renan Luiz Albuquerque Vieira4; Claudinéia Silva Mendes ${ }^{1}$; Monna \\ Lopes de Araújo ${ }^{4}$; Ana Lúcia Almeida Santana5; Larissa Pires Barbosa ${ }^{5^{*}}$
}

\section{Highlights}

Traditionally used doses of eCG and $\mathrm{PGF}_{2} \alpha$ in sheep protocols are overestimated.

The study offers yet another alternative route for hormonal administration.

The study shows alternatives to reduce the cost of the protocol for sheep.

\begin{abstract}
Here, the efficiency of applying subdoses of equine chorionic gonadotropin (eCG) and prostaglandin $\mathrm{F}_{2} \alpha$ $\left(\mathrm{PGF}_{2} \alpha\right)$ at the Bai Hui $(\mathrm{BH})$ acupoint for estrus synchronization in sheep was evaluated. Thirty Santa Inês ewes received intravaginal sponges containing $60 \mathrm{mg}$ medroxyprogesterone acetate for 7 days. The animals were divided into five treatments (T) ( $n=6)$ : T1 (control), $132.5 \mu \mathrm{g} \mathrm{PGF}{ }_{2} \alpha(100 \%$ of dose) and 300 IU eCG (100\% of dose), both intramuscularly (IM); T2, $39.75 \mu$ PGF $_{2} \alpha$ (30\% of dose) at the BH acupoint and 300 IU eCG (100\% of dose) IM; T3, $132.5 \mu$ PGF $_{2} \alpha$ (100\% of dose) IM and 90 IU eCG (30\% of dose) at the BH acupoint; T4, $39.75 \mu \mathrm{PGF}_{2} \alpha$ (30\% of dose) and 90 IU eCG (30\% of dose), both at the BH acupoint; and T5, $39.75 \mu \mathrm{PGF}_{2} \alpha$ (30\% of dose) and 90 IU eCG (30\% of dose) both at a false acupoint (IM, at the same location as in T1). After $12 \mathrm{~h}$ of sponge removal and hormone application, the ewes were subjected to monitoring for estrus and mating and ultrasound assessments of follicular growth and ovulation time every $12 \mathrm{~h}$. The data were evaluated for normality and subjected to analysis of variance, considering a

${ }^{1}$ Master in Animal Science, Post-Graduate Program in Animal Science, Universidade Federal do Recôncavo da Bahia, UFRB, Cruz das Almas, BA, Brazil. E-mail: pantaneiro.diego@gmail.com; caumendes18@gmail.com

2 Doctor in Animal Science in the Tropics, Post-Graduate Program in Animal Science in the Tropics, Universidade Federal da Bahia, UFBA, Salvador, BA, Brazil. E-mail: ceabiscarde@yahoo.com.br

3 Student of the Doctoral Course of the Post-Graduate Program in Animal Science, Universidade Estadual de Santa Cruz, UESC, Ilhéus, BA, Brazil. E-mail: william.moraiss@hotmail.com

4 Students of the Doctoral Course of the Post-Graduate Program in Animal Science in the Tropics, UFBA, Salvador, BA, Brazil. E-mail: renan.albuquerque@hotmail.com; monnalopes@hotmail.com

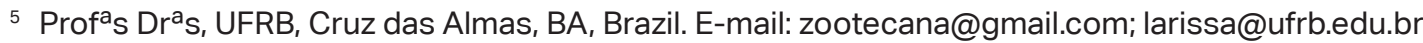

* Author for correspondence
\end{abstract}

Received: July 16, 2020 - Approved: Apr. 15, 2021 
$5 \%$ probability. There were no differences in the percentage of animals in estrus $(93.3 \pm 9.1 \%)$, interval from sponge removal to estrus onset $(48.1 \pm 6.0 \mathrm{~h})$, interval from sponge removal to estrus end $(69.6 \pm 5.4$ h), duration of estrus $(24.0 \pm 4.7 \mathrm{~h})$, interval from sponge removal to ovulation $(73.7 \pm 5.9 \mathrm{~h})$, interval from estrus onset to ovulation $(26.5 \pm 2.3 \mathrm{~h})$, size of the largest follicle $(6.7 \pm 0.4 \mathrm{~mm})$, follicular growth rate $(0.8 \pm 0.1$ $\mathrm{mm} \cdot$ day $\left.^{-1}\right)$, number of ovulations $(1.3 \pm 0.1)$, and plasma progesterone levels 7 days after ovulation $(9.6 \pm 2.0$ $\left.\mathrm{ng} \cdot \mathrm{mL}^{-1}\right)$. The cost of the synchronization protocol per animal was US\$4.37, 4.12, 2.96, 2.71, and 2.71 for T1, T2, T3, T4, and T5, respectively, with $37.99 \%$ cost reduction using $\mathrm{PGF}_{2} \alpha$ and eCG at $30 \%$ of the conventional doses. Therefore, the application of reduced $\mathrm{PGF}_{2} \alpha(39.75 \mu \mathrm{g})$ and eCG (90 IU) doses at the $\mathrm{BH}$ or false acupoint effectively synchronized estrus and reduced protocol cost in sheep, indicating that the conventional doses are overestimated.

Key words: Acupuncture. Equine chorionic gonadotropin. Prostaglandin $F_{2} \alpha$.

\section{Resumo}

Aqui, foi avaliada a eficiência da aplicação de subdoses de gonadotrofina coriônica equina (eCG) e prostaglandina $\mathrm{F}_{2} \alpha\left(\mathrm{PGF}_{2} \alpha\right)$ no ponto de acupuntura Bai Hui $(\mathrm{BH})$ para sincronização de estro em ovelhas. Trinta ovelhas Santa Inês receberam esponjas intravaginais contendo $60 \mathrm{mg}$ de acetato de medroxiprogesterona por 7 dias. Os animais foram divididos em cinco tratamentos (T) ( $n=6)$ : T1 (controle), $132,5 \mu \mathrm{g} \mathrm{PGF} \alpha$ (100\% da dose) e $300 \mathrm{UI}$ de eCG (100\% da dose), ambos por via intramuscular (IM); T2, $39,75 \mu \mathrm{g}$ de $\mathrm{PGF}_{2} \alpha$ (30\% da dose) no ponto de acupuntura BH e $300 \mathrm{UI}$ eCG (100\% da dose) IM; T3, 132,5 $\mu \mathrm{g} \mathrm{PGF}{ }_{2} \alpha\left(100 \%\right.$ da dose) IM e $90 \mathrm{Ul} \mathrm{eCG} \mathrm{(30 \%} \mathrm{da} \mathrm{dose)} \mathrm{no} \mathrm{ponto} \mathrm{de} \mathrm{acupuntura} \mathrm{BH;} \mathrm{T4,} \mathrm{39,75} \mu$ g PGF ${ }_{2} \alpha$ (30\% da dose) e $90 \mathrm{UI}$ eCG (30\% da dose), ambos no ponto de acupuntura BH; e T5, 39,75 $\mu$ g PGF 2 ( $30 \%$ da dose) e $90 \mathrm{UI}$ eCG (30\% da dose) ambos em um falso acuponto (IM, no mesmo local que em T1). Após 12 horas da retirada da esponja e aplicação do hormônio, as ovelhas foram submetidas ao monitoramento do estro e acasalamento, e avaliação ultrassonográfica do crescimento folicular e tempo de ovulação a cada 12 horas. Os dados foram avaliados quanto à normalidade e submetidos à análise de variância, considerando $5 \%$ de probabilidade. Não houve diferenças na porcentagem de animais em estro $(93,3 \pm$ $9,1 \%)$, intervalo da remoção da esponja ao início do estro $(48,1 \pm 6,0$ h), intervalo da remoção da esponja ao final do estro $(69,6 \pm 5,4$ h), duração do estro $(24,0 \pm 4,7 \mathrm{~h})$, intervalo da remoção da esponja à ovulação $(73,7 \pm 5,9 \mathrm{~h})$, intervalo do início do estro à ovulação $(26,5 \pm 2,3 \mathrm{~h})$, tamanho do maior folículo $(6,7 \pm 0,4 \mathrm{~mm})$, taxa de crescimento folicular $\left(0,8 \pm 0,1 \mathrm{~mm} \mathrm{dia}^{-1}\right)$, número de ovulações $(1,3 \pm 0,1)$ e níveis de progesterona plasmática 7 dias após a ovulação $\left(9,6 \pm 2,0 \mathrm{ng} \cdot \mathrm{mL}^{-1}\right)$. O custo do protocolo de sincronização por animal foi de US $\$ 4,37,4,12,2,96,2,71$ e 2,71 para T1, T2, T3, T4 e T5, respectivamente, com redução de custo de $37,99 \%$ usando $\mathrm{PGF}_{2} \alpha$ e eCG a 30\% das doses convencionais. Portanto, a aplicação de $\mathrm{PGF}_{2} \alpha(39,75 \mu \mathrm{g})$ e doses reduzidas de eCG (90 UI) no $\mathrm{BH}$ ou falso acuponto sincronizaram efetivamente o estro e reduziram o custo do protocolo em ovelhas, indicando que as doses convencionais estão superestimadas.

Palavras-chave: Acupuntura. Gonadotrofina coriônica equina. Prostaglandina $F_{2} \alpha$. 


\section{Introduction}

The techniques of estrus synchronization using progestogens for sheep date back to the 1960s. A considerable amount of information on estrus synchronization in small ruminants was produced and published in the 1970s and 1980s, which laid the foundation for majority of the studies performed today (Wildeus, 2000). Subsequently, this progress has prompted the search for the minimum effective doses of hormones used, with the objective of reducing the cost of protocols and physiological impact on females.

This search for the minimum effective doses, among other options, involves the evaluation of different hormonal application routes. The Bai Hui $(\mathrm{BH})$ and $\mathrm{Hou} \mathrm{Hai}(\mathrm{HH})$ acupuncture points are linked to the reproductive organs, and some techniques using these acupoints have been developed for the treatment or assessment reproductive protocols in ruminants, including the $\mathrm{BH}$ acupoint in goats (Souza et al., 2019; R. C. S. A. Araújo et al., 2019) and sheep (Martinez, Oliveira, Cadamuro, Bonamigo, \& Folador, 2007 ) and the Hou Hai acupoint in goats ( $R$. C. Cardoso et al., 2018; R. C. S. A. Araújo et al., 2019) and bovine (M. L. Araújo et al., 2019).

Pharmacopuncture involves the application of drugs at specific acupoints with the aim of potentiating the effect of drug applied at these sites. Thus, subdoses applied at acupoints may produce a longer-lasting effect, similar to the conventional doses, with the added advantage of fewer collateral effects (Scognamillo-Szabó \& Bechara, 2010). The $\mathrm{BH}$ acupoint is located in the lumbosacral space, and it is easy to access for drug administration. According to Lin, Chan and
Wu (2006), this acupoint can be used for the treatment of reproductive disorders.

To this end, the objective of the present study was to evaluate the efficiency of applying $30 \%$ of the conventional doses of equine chorionic gonadotropin (eCG) and prostaglandin $\mathrm{F}_{2} \alpha\left(\mathrm{PGF}_{2} \alpha\right)$ in acupoint $\mathrm{BH}$ for estrus synchronization in sheep.

\section{Material and Methods}

The present study was performed at the Federal University of the Recôncavo of Bahia (UFRB), Cruz das Almas, from March to April, the transition period from the dry to rainy season. The study protocol was approved by the Ethics Committee on Animal Use of UFRB (approval number 23007.0098 10/2011-28).

Thirty pluriparous Santa Inês ewes were selected. The ewes were between 2 and 4 years of age and presented a body condition score between 2.5 and 3.5 on a scale of 1 to 5 . Their average weight was $38.3 \pm 5.3 \mathrm{~kg}$, and they were outside the lactation period. The animals were managed in an intensive production system. They were housed in collective stalls and provided chopped sugar cane (Saccharum officinarum L.), mineral supplement, and water ad libitum.

All ewes received intravaginal sponges with $60 \mathrm{mg}$ medroxyprogesterone acetate (Progespon, Syntex, Argentina) for 7 days, and each sponge was applied with $0.1 \mathrm{mg}$ oxytetracycline (Kuramicina König of Brazil LTDA). When removing the sponges, the animals were randomly distributed into five groups (T1, T2, T3, T4, and T5), as shown in Table 1. 
Table 1

Experimental treatments

\begin{tabular}{|ccc|}
\hline Treatment $(\mathrm{n}=6)$ & $\mathrm{D} 6 \mathrm{eCG}$ & $\mathrm{D} 7 \mathrm{PGF}_{2} \alpha$ \\
\hline 1 & $\mathrm{IM} \mathrm{100 \%}$ & $\mathrm{IM} \mathrm{100 \%}$ \\
2 & $\mathrm{IM} \mathrm{100 \%}$ & $\mathrm{BH} 30 \%$ \\
3 & $\mathrm{BH} 30 \%$ & $\mathrm{IM} \mathrm{100 \%}$ \\
4 & $\mathrm{BH} 30 \%$ & $\mathrm{BH} 30 \%$ \\
\hline 5 & $\mathrm{IM} \mathrm{30 \%}$ & $\mathrm{IM} \mathrm{30 \%}$ \\
\hline
\end{tabular}

Dose eCG 100\% $=300 \mathrm{IU}$ and dose $\mathrm{PGF}_{2} \alpha 100 \%=132,5 \mu \mathrm{g} ; \mathrm{IM}$ - Intramuscular; $\mathrm{PGF}_{2} \alpha$ - Prostaglandina $\mathrm{F}_{2} \alpha$ (Cloprostenol sodium - Ciosin, Coopers, Brazil); eCG - Equine Chorionic Gonadotropin (Novormon, Coopers, Brasil).

Throughout the experimental period, temperature and humidity were measured using a thermo-hygrometer (THAL-300, Higro Term Anemometer Digital Luxmeter/ Instrutherm) every day at $10 \mathrm{AM}$ and $4 \mathrm{PM}$, and the mean temperature and humidity were $31.11^{\circ} \mathrm{C}$ and $60.0 \%$, respectively.

For hormonal application at the $\mathrm{BH}$ acupoint, trichotomy of the area and antisepsis with povidone-iodine (Riodeine, Rioquímica, São Paulo, Brazil) were performed. The $\mathrm{BH}$ acupoint is located between the last lumbar vertebra and the first sacral vertebra, located by palpation and with insertion of the needle above medullary canal. A $25 \times 7$ $\mathrm{mm}$ hypodermic needle was inserted at a $90^{\circ}$ angle to the skin. For application at a false acupoint, intramuscular (IM) administration was performed in the semitendinosus muscle of the posterior limb, in the same way as the IM application of other treatments.

The following reproductive parameters were evaluated: percentage of animals in estrus, interval between sponge removal and estrus onset, interval between sponge removal and estrus end, and duration of estrus. After sponge removal, the animals were monitored for estrus expression every 12 hours. Standing immobile for mount were considered the signs of estrus onset, and mount rejection was considered a sign of estrus end.

To evaluate follicular growth and ovulation time, ultrasound assessments were performed immediately after sponge removal and at 12-h intervals thereafter until $12 \mathrm{~h}$ after ovulation. Images of the ovaries were obtained transrectally using an ultrasound machine (Pie Medical, model ÀquilaVet) coupled to a $6.0 \mathrm{MHz}$ linear transducer. The ovaries were located as described previously (Ginther \& Kot, 1994).

The following follicular growth and ovulation parameters were evaluated: interval from sponge removal to ovulation, interval from estrus onset to ovulation, follicular growth rate, and diameter of the largest and second largest follicle. The interval from sponge removal to ovulation and from estrus onset to ovulation was measured in hours. The ovulation time was calculated as the average between the time of the last observation of an ovulatory follicle and the time of disappearance of that ovulatory follicle. The follicle growth rate $\left(\mathrm{mm} \bullet \mathrm{day}^{-1}\right)$ was calculated as the difference between the final and initial diameters, divided by the number of hours, and the obtained value was multiplied by 24 to achieve the daily growth rate. 
The follicular diameter was measured as the length of the largest antral cavity, and the follicle with the largest diameter was considered dominant. Only one subordinate follicle was considered, classified as the one that appeared simultaneously with the dominant follicle but had a smaller diameter and shorter persistence.

To measure plasma progesterone concentration, blood was collected from the animals 7 days after ovulation via venipuncture of the jugular vein using vacuum tubes containing EDTA. The blood samples were centrifuged at 3,000 rpm for $15 \mathrm{~min}$ to separate plasma. The chemiluminescence method was used to determine plasma progesterone concentration using a commercial kit (Access Progesterone, Beckman Coulter).

To calculate the protocol cost, the market value of the used hormones was considered (Table 2), and the final cost was determined as the sum of the cost of each treatment, calculated as follows:

\section{Table 2}

Hormone value quoted in March 2021

Hormone

Cost US\$
Sponge

(25 units)

49.90
$\mathrm{PGF}_{2} \alpha$ $\left(5 \mathrm{mg} \cdot 20 \mathrm{~mL}^{-1}\right)$

13.56
eCG $\left(5.000 \mathrm{IU} \cdot 25 \mathrm{~mL}^{-1}\right)$

33.57

$\mathrm{PGF}_{2} \alpha$ - Prostaglandina $\mathrm{F}_{2} \alpha$; eCG - Equine Chorionic Gonadotropin; The exchange rate from the Real to the Dollar was made considering the quotation of the commercial Dollar, at the purchase price as quoted by the Central Bank of Brazil on its website (https://www.bcb.gov.br/) on March 22, 2021.

Hormone cost per protocol $=$ Volume administered $(\mathrm{mL}) \times$ Total hormone cost

Total volume of the bottle $(\mathrm{mL})$

The data were evaluated for normality using the Shapiro-Wilk test. The variables presented a normal distribution and were subjected to analysis of variance with $5 \%$ significance. SPSS 2015 was used for all analyses.

\section{Results and Discussion}

The reduction of $\mathrm{PGF}_{2} \alpha$ and $\mathrm{eCG}$ doses to $30 \%$ of the conventional doses administered in estrus synchronization protocols for sheep did not affect the percentage of animals in estrus $(93.3 \pm 9.1 \%)$, interval between sponge removal and estrus onset $(48.1 \pm 6.0 \mathrm{~h})$, interval between sponge removal and estrus end (69.6 $\pm 5.4 \mathrm{~h})$, and duration of estrus $(24.0 \pm 4.7$ h) $(P>0.05)$ (Table 3). These results indicate that physiologically, when administered at $30 \%$ of the conventional dose, $\mathrm{PGF}_{2} \alpha$ was efficient in regressing the corpus luteum (CL) and eCG could induce synchronized follicular growth. 


\section{Table 3}

Estrus behavior of sheep submitted to estrus synchronization protocols with hormonal application in the Bai Hui or intramuscular acupoint

\begin{tabular}{|ccccccc|}
\hline Variables & T1 & T2 & T3 & T4 & T5 & Mean \\
\hline Estrus (\%) & 100 & 100 & 100 & 83.3 & 83.3 & $93.3 \pm 9.1$ \\
\hline Start of estrus (h) & $42.0 \pm 14.7$ & $44.0 \pm 9.8$ & $54.0 \pm 6.6$ & $55.2 \pm 13.7$ & $45.6 \pm 10.0$ & $48.1 \pm 6.0$ \\
\hline Finale of estrus (h) & $62.0 \pm 4.9$ & $72.0 \pm 7.6$ & $68.0 \pm 9.8$ & $76.8 \pm 10.7$ & $69.6 \pm 10.0$ & $69.6 \pm 5.4$ \\
\hline Estrus duration (h) & $21.0 \pm 4.9$ & $30.0 \pm 8.5$ & $18.0 \pm 10.0$ & $24.0 \pm 12.0$ & $27.0 \pm 6.0$ & $24.0 \pm 4.7$ \\
\hline
\end{tabular}

$\mathrm{T} 1=100 \%$ of the eCG and $\mathrm{PGF}_{2} \alpha$ dose intramuscularly, T2 $=100 \%$ of the eCG dose and $30 \%$ of the PGF $\alpha$ dose in the Bai Hui acupoint, T3 $=30 \%$ of the eCG dose in the Bai Hui acupoint and $100 \%$ of the dose of intramuscular PGF $\alpha$, T4 $_{2}=$ $30 \%$ of the dose of eCG and PGF 2 in the Bai Hui acupoint, T5 $=30 \%$ of the dose of eCG and PGF $\alpha$ in the false acupoint. The data refer to the mean \pm standard deviation and there was no difference between treatments through Analysis of Variance $(P>0.05)$.

To date, pharmacopuncture has rarely been used in estrus synchronization protocols for sheep. The present study offers hormonal application at an acupuncture point as an alternative estrus synchronization approach in sheep, with the main objective of reducing the hormonal doses used and, consequently, their costs. It is often a common goal, regardless of the species, to verify the lowest effective hormonal dose.

According to Nogueira et al. (2019), estrus expression in an important evaluation parameter. In fixed-time artificial insemination (FTAl) programs, estrus expression is associated with increased female fertility and estrus detection improves fertility, although precise estrus detection may be difficult and laborious using traditional methods.

The estrus behavioral display was directly correlated to the luteolytic efficiency of possible CL present during the protocol and, consequently, blood progesterone levels and follicular steroid production, which are dependent on gonadotropins (R. C. Cardoso et al., 2018). As the percentage of animals in estrus in the present study was not affected by the reduction of hormonal doses, $\mathrm{PGF}_{2} \alpha$ and eCG applied at $30 \%$ of the conventional doses efficiently produced their expected biological effects.

A study testing $30 \%$ of the conventional doses of $\mathrm{PGF}_{2} \alpha$ and $\mathrm{eCG}$ applied at the $\mathrm{BH}$ acupoint in goats did not find differences in estrus expression, with the average rate of estrus detection of approximately 95\% (Souza et al., 2019). Likewise, another study testing even smaller doses $(20 \%$ and $10 \%$ of the conventional doses) of $\mathrm{PGF}_{2} \alpha$ and eCG applied at the $\mathrm{BH}$ acupoint in goats did not find any difference in estrus expression $(80 \%$ and $77.7 \%$, respectively) (R. C. S. A. Araújo et al., 2019).

R. C. Cardoso et al. (2018) tested the application of a hormone at $30 \%$ of the conventional dose at the Hou Hai acupoint in goats and found a decrease in estrus expression (74\%) compared with the control value $(100 \%)$ and the value obtained when 
the hormone was applied at a false acupoint (91.3\%). These reports (R. C. Cardoso et al., 2018) suggest that the selection of acupoint can affect the efficiency of hormone action. In addition, the ease of access of the acupoint must also be taken into account, as the $\mathrm{Hou} \mathrm{Hai}$ acupoint, located in the depression between the average distance from the ventral base of the tail and the anus, is difficult to reach. Importantly, according to Lin et al. (2006), the Hou Hai acupoint, which is also linked to the reproductive organs and, can be used to treat reproductive problems, such as anestrus, cystic ovaries, cystic or retained $\mathrm{CL}$, silent estrus, and pseudocyesis.

The observed percentage of animals in estrus $(93.3 \pm 9.1 \%)$ was expected because of the use of hormones for estrus synchronization and the onset of mount season (Gardón, Escribano, Astiz, \& Ruiz, 2015). Fonseca et al. (2003) reported that the estrus synchronization response may vary from $60 \%$ to $100 \%$, and environmental, individual, health, and nutritional factors affect this response.

Regardless of the dose and application site, there were no differences in the interval between sponge removal and estrus onset or end as well as the duration of estrus. Estrus onset is associated with its duration, and it is an important parameter in FTAl programs to determine the best time for artificial insemination. In previous studies, the reported interval from device removal to estrus onset $(48.1 \pm 6.0 \mathrm{~h})$ was within the expected range for sheep (Cavalcanti, Brandão, Nogueira, \& Fonseca, 2012; Prates et al., 2019).

Furthermore, R. C. Cardoso et al. (2018) and Souza et al. (2019) tested the application of $30 \%$ hormonal subdoses at different acupoints $(\mathrm{BH}$ and $\mathrm{HH})$ in goats and observed differences between neither the observed interval from device removal to estrus onset or end nor the duration of estrus and the control values. These reports suggest that the conventional doses of hormones for sheep are overestimated.

Follicular growth and ovulation time were not affected by the tested doses and hormone application routes $(P>0.05)$. Moreover, the tested doses did not affect the ovulation rate $(93.33 \%)$, interval from sponge removal to ovulation $(73.7 \pm 5.9 \mathrm{~h})$, interval from estrus onset to ovulation $(26.5 \pm 2.3 \mathrm{~h})$, diameter of the largest follicle $(6.7 \pm 0.0 \mathrm{~mm})$, diameter of the second largest follicle $(5.4 \pm 0.2$ $\mathrm{mm})$, follicular growth rate $\left(0.8 \pm 0.1 \mathrm{~mm}^{\bullet} \mathrm{day}^{-1}\right)$, and ovulation number (1.3 \pm 0.1$)$ (Table 4). 
Table 4

Follicular growth, moment of ovulation and plasma progesterone concentration of sheep submitted to estrus synchronization protocols with hormonal application in the Bai Hui or intramuscular area

\begin{tabular}{ccccccc}
\hline Variables & T1 & T2 & T3 & T4 & T5 & Mean \\
\hline Ovulation $(\%)$ & 100 & 100 & 100 & 83.33 & 83.33 & 93.33 \\
Ovulation time $(\mathrm{h})$ & $70.0 \pm 14.0$ & $72.0 \pm 7.5$ & $78.0 \pm 12.5$ & $81.6 \pm 13.1$ & $67.2 \pm 16.0$ & $73.7 \pm 5.9$ \\
\hline Estrus-Ovulation $(\mathrm{h})$ & $28.0 \pm 14.5$ & $28.0 \pm 6.1$ & $24.0 \pm 7.5$ & $28.8 \pm 10.7$ & $24.0 \pm 14.6$ & $26.5 \pm 2.3$ \\
Larger follicle diameter $(\mathrm{mm})$ & $6.4 \pm 0.7$ & $6.3 \pm 0.6$ & $6.6 \pm 0.7$ & $6.9 \pm 0.9$ & $7.2 \pm 0.9$ & $6.7 \pm 0.4$ \\
\hline Second follicle diameter $(\mathrm{mm})$ & $5.3 \pm 1.2$ & $5.6 \pm 0.8$ & $5.3 \pm 1.1$ & $5.2 \pm 1.4$ & $5.6 \pm 0.9$ & $5.4 \pm 0.2$ \\
Follicular growth rate $\left(\mathrm{mm}^{-1} \mathrm{~d}^{-1}\right)$ & $0.88 \pm 0.2$ & $0.93 \pm 0.3$ & $0.72 \pm 0.2$ & $0.78 \pm 0.2$ & $0.95 \pm 0.5$ & $0.85 \pm 0.1$ \\
Number of ovulations & $1.50 \pm 0.5$ & $1.33 \pm 0.5$ & $1.33 \pm 0.5$ & $1.60 \pm 0.5$ & $1.20 \pm 0.4$ & $1.39 \pm 0.1$ \\
$\mathrm{P}_{4}\left(\mathrm{ng} \cdot \mathrm{mL}^{-1}\right)$ & $9.8 \pm 2.5$ & $12.4 \pm 2.8$ & $8.6 \pm 2.8$ & $10.2 \pm 5.1$ & $6.8 \pm 3.8$ & $9.6 \pm 2.0$ \\
\hline
\end{tabular}

$\mathrm{P}_{4}=$ plasma progesterone concentration. $\mathrm{T} 1=100 \%$ of the eCG and $\mathrm{PGF}_{2} \alpha$ dose intramuscularly, $\mathrm{T} 2=100 \%$ of the eCG dose and $30 \%$ of the $\mathrm{PGF}_{2} \alpha$ dose in the Bai Hui acupoint, T3 $=30 \%$ of the eCG dose in the Bai Hui acupoint and $100 \%$ of the dose of intramuscular PGF ${ }_{2} \alpha, \mathrm{T}_{4}=30 \%$ of the dose of eCG and PGF $\alpha$ in the Bai Hui acupoint, T5 $=30 \%$ of the dose of eCG and $\mathrm{PGF}_{2} \alpha$ in the false acupoint. The data refer to the mean \pm standard deviation and there was no difference between treatments through Analysis of Variance $(P>0.05)$.

All animals that presented estrus also achieved ovulation, with an average rate of $93.33 \%$. Ovulation occurred at $73.7 \pm 5.9 \mathrm{~h}$ after sponge removal, which was similar to the previously reported intervals [70.4 $\mathrm{h}$ by Teixeira et al. (2016) and $80.4 \mathrm{~h}$ by Moreira, Brasil, Silva and Ramos (2014)] in Santa Inês sheep. Ovulation duration is another important parameter. According to the protocols used in this study, ovulation occurred at the maximum interval of 25.24 $h$, regardless of the dose and hormone used, indicating efficient ovulation synchronization and high possibility of successful FTAI. These results corroborate the findings of Vilariño, Cuadro, Santos, García-Pintos and Menchaca (2017), who reported that a protocol achieving ovulation synchronization within a 24 -h period is suitable for FTAl.

In the present study, the mean diameter was $6.7 \pm 0.4 \mathrm{~mm}$ for the largest follicle and $5.4 \pm 0.2 \mathrm{~mm}$ for the second largest follicle, and these values are within the expected range for sheep ( $>5 \mathrm{~mm}$ ) (Seekallu et al., 2010). These results indicate that similar to the control protocol, the test protocols used were efficient, particularly treatments with reduced hormonal doses. B. M. Cardoso et al. (2012) have reported similar results in Santa Inês sheep (mean diameter, $7.4 \pm 1.0 \mathrm{~mm}$ for the largest follicle and $5.4 \pm 1.0 \mathrm{~mm}$ for the second largest follicle). Therefore, a 30\% eCG dose is sufficient to generate good-quality follicles.

Plasma progesterone concentration at 7 days after ovulation did not differ among the protocols used, with an average value of $9.6 \pm 2.0 \mathrm{ng} \cdot \mathrm{mL}^{-1}(P>0.05)$ (Table 4). This result suggests that the tested protocols promoted adequate $\mathrm{CL}$ formation, since progesterone concentration is a reliable indicator of $\mathrm{CL}$ formation. Leyva, Buckrell and Walton (1998) administered progesterone to sheep during the estrus cycle and observed that plasma progesterone concentration was elevated on 
the day after ovulation $\left(0.8 \mathrm{ng} \cdot \mathrm{mL}^{-1}\right)$, although the increase was significant only from the second day $\left(2.4 \pm 0.3 \mathrm{ng} \cdot \mathrm{mL}^{-1}\right)$ onward; as such, the progesterone concentration increased until the sixth or seventh day of the estrus cycle $\left(7.6 \pm 0.4 \mathrm{ng} \cdot \mathrm{mL}^{-1}\right)$ but remained fluctuating until day 10 .

The cost of protocol per animal was US\$ 4.37, 4.12, 2.96, 2.71, and 2.71 for T1, T2, T3, T4, and T5, respectively, with $37.99 \%$ cost reduction with the application of $\mathrm{PGF}_{2} \alpha$ and eCG at $30 \%$ of the conventional doses. Therefore, the application of reduced $\mathrm{PGF}_{2} \alpha$ and $\mathrm{eCG}$ doses at the $\mathrm{BH}$ point is both efficient and economic.

\section{Conclusion}

The application of reduced doses of $\mathrm{PGF}_{2} \alpha(39.75 \mu \mathrm{g})$ and eCG $(90 \mathrm{IU})$ at the $\mathrm{BH}$ or false acupoint, corresponding to $30 \%$ of the conventional doses used in estrus synchronization protocols for sheep, was efficient in promoting estrus expression and luteolysis, successfully achieving estrus synchronization and ovulation, while reducing the protocol cost, in Santa Inês sheep. The present study offers an alternative method of hormonal application for the pharmacological control of the estrus cycle in sheep.

\section{References}

Araújo, M. L, Mendes, C. S., Biscarde, C. E. A., Biscarde, F. H. A., Rocha, L. F., Costa, L. N. F.,... Barbosa, L. P. (2019). Application of low dose of equine chorionic gonadotropin at acupoint Hou Hai for fixed-time artificial insemination in beef cows. Semina: Ciências Agrárias, 40(6), 2625-2636. doi: 10.5433/1679-0359.2019v40n6p2625
Araújo, R. C. S. A., Barbosa, L. P., Souza, R. S., Santana, A. L. A., Carneiro, I. M. B., Machado, W. M.,... Jesus, R. D. L. (2019). Farmacopuntura utilizando os acupontos Hou Hai e Bai Hui em protocolos de sincronização de estro em cabras. Arquivo Brasileiro de Medicina Veterinária e Zootecnia, 71(2), 529-537. doi: 10.15 90/1678-4162-10333

Cardoso, B. M., Neto, Barbosa, L. P., Aguiar, C. S., Souza, R. S., Santana, A. L. A., Mendes, C. S.,... Leite, M. C. P. (2012). Folliclestimulating hormone to substitute equine chorionic gonadotropin in the synchronization of ovulation in Santa Inês ewes. Revista Brasileira de Zootecnia, 41(3), 603-606. doi: 10.1590/S1516-35 982012000300018

Cardoso, R. C., Barbosa, L. P., Souza, R. S., França, C. S., Ribeiro, M. D. M., Jr., Santana, A. L. A.,... Santos, R. S. (2018). Application of hormonal subdoses at acupoint $\mathrm{Hou}$ $\mathrm{Hai}$ in estrus synchronization protocols of goats. Semina: Ciências Agrárias, 39(3), 1135-1142. doi: 10.5433/1679-03 59.2018v39n3 p1135

Cavalcanti, A. S., Brandão, F. Z., Nogueira, L. A. G., \& Fonseca, J. F. (2012). Effects of $\mathrm{GnRH}$ administration on ovulation and fertility in ewes subjected to estrous synchronization. Revista Brasileira de Zootecnia, 41(6), 1412-1418. doi: 10.15 90/S1516-35982012000600014

Fonseca, J. F., Torres, C. A. A., Maffili, V. V., Prosperi, C. P., Santos, A. D. F., Borges, A. M.,... Rubert, M. (2003). Indução hormonal de estro em cabras nulíparas na estação de anestro. Revista Brasileira de Reprodução Animal, 27, 528-530. 
Gardón, J. C., Escribano, B., Astiz, S., \& Ruiz, S. (2015). Synchronization protocols in Spanish Merino sheep: reduction in time to estrus by the addition of eCG to a progesterone-based estrus synchronization protocol. Annals of Animal Science, 15(2), 409-418. doi: 10.15 15/aoas-2015-0003

Ginther, O. J., \& Kot, K. (1994). Follicular dynamics during the ovulatory season in goats. Theriogenology, 42(6), 987-1001. doi: 10.1016/0093-691X(94)90121-X

Leyva, V., Buckrell, B. C., \& Walton, J. S. (1998). Regulation of follicular and ovulation in ewes by exogenous progestagen. Theriogenology, 50(3), 395-416. doi: 10. 1016/S0093-691X(98)00148-4

Lin, J. H., Chan, W. W., Wu, L. S. (2006). Acupuntura para tratar distúrbios reprodutivos. In: A. M. Schoen (Ed.), Acupuntura veterinária: da arte antiga à medicina moderna. (2a ed. pp. 258-264). São Paulo: Editora Roca, 2006.

Martinez, A. C., Oliveira, F. S., Cadamuro, V. A. H., Bonamigo, C. G., \& Folador, M. (2007). Uso de baixa dose de cloprostenol sódico administrado pelo ponto Bai Hui de acunpuntura em ovelhas. Archivos Veterinary Science, 12(Supl.), 231-232.

Moreira, N. H., Brasil, O. O., Silva, J. P., \& Ramos, A. F. (2014). Utilização de FSH:LH como alternativa para estimular o crescimento folicular na sincronização do estro ovino. Acta Scientiae Veterinariae, 42, 1-7.

Nogueira, E., Silva, M. R., Silva, J. C. B., Abreu, U. P. G., Anache, N. A., Silva, K. C.,... Rodrigues, W. B. (2019). Timed artificial insemination plus heat I: effect of estrus expression scores on pregnancy of cows subjected to progesterone-estradiol-based protocols.
Animal, 13(10), 2313-2318. doi: 10.1017/ S1751731119000442

Prates, J. F., Brair, V. L., Maia, A. L. R. S., SouzaFabjan, J. M. G., Brandão, F. Z., Bonato, G. C., \& Fonseca, J. F. (2019). Use of human intravaginal tampon embedded with natural progesterone induces synchronous estrus in Santa Inês ewes. Arquivo Brasileiro de Medicina Veterinária e Zootecnia, 71(1), 345-348. doi: 10-15 90/1678-4162-10241

Scognamillo-Szabó, M. V. R., \& Bechara, G. H. (2010). Acupuncture: history, basic principles and its use in veterinary medicine. Ciência Rural, 40(2), 1-13. doi: 10.1590/S0103-84782010005000004

Seekallu, S. V., Toosi, B. M., Duggavathi, R., Barrett, D. M. W., Davies, K. L., Waldner, C., \& Rawlings, N. C. (2010). Ovarian antral follicular dynamics in sheep revisited: Comparison among estrous cycles with three or four follicular waves. Theriogenology, 73(5), 670-680. doi: 10. 1016/j.theriogenology.2009.11.007

Souza, D. O., Araujo, M. L., Biscarde, C. E. A., Mendes, C. S., Silva, M. A. A., Romero, D. C. M. R.,... Barbosa, L. P. (2019). Use of hormonal subdoses applied in Bai Hui acupuncture in estrus synchronization protocols for goats. Semina: Ciências Agrárias, 40(4), 1501-1512. doi: 10.5433 /1679-0359.2019v40n4p1501

Teixeira, T. A., Fonseca, J. F., Souza-Fabjan, J. M. G., Carvalheira, L. R., Fernandes, D. A. M., \& Brandão, F. Z. (2016). Efficiency of different hormonal treatments for estrus synchronization in tropical Santa Inês sheep. Tropical Animal Health Production, 48(3), 545-551. doi: 10.1007/s11250-01 5-0989-y 
Vilariño, M., Cuadro, F., Santos, P.C., Neto, GarcíaPintos, C., \& Menchaca, A. (2017). Time of ovulation and pregnancy outcomes obtained with the prostaglandina-based protocol Synchrovine for FTAI in sheep. Theriogenology, 90(1), 163-168. doi: 10. 1016/j.theriogenology.2016.12.003
Wildeus, S, (2000). Current concepts in synchronization of estrus: Sheep and goats. Journal of AnimalScience, 77(Supl.), 1-14. doi: 10.2527/jas2000.0021881200 7700ES0040x 
